\title{
Pathomechanisms of Autoimmune Based Testicular Inflammation
}

\begin{abstract}
Livia Lustig ${ }^{1,2 *}$, Vanesa A. Guazzone 1,2, María S. Theas ${ }^{1,2}$, Christiane Pleuger ${ }^{3,4}$, Patricia Jacobo ${ }^{1,2}$, Cecilia V. Pérez ${ }^{2}$, Andreas Meinhardt ${ }^{3,4}$ and Monika Fijak ${ }^{3,4 *}$

${ }^{1}$ Departamento de Biología Celular e Histología/Unidad Académica II, Facultad de Medicina, Universidad de Buenos Aires (UBA), Buenos Aires, Argentina, ${ }^{2}$ Instituto de Investigaciones Biomédicas (INBIOMED), Consejo Nacional de Investigaciones Científicas y Tècnicas (CONICET), Universidad de Buenos Aires (UBA), Buenos Aires, Argentina, ${ }^{3}$ Department of Anatomy and Cell Biology, Justus-Liebig University Giessen, Giessen, Germany, ${ }^{4}$ Hessian Centre of Reproductive Medicine, Justus-Liebig University Giessen, Giessen, Germany
\end{abstract}

Infection and inflammation of the male reproductive tract are relevant causes of infertility. Inflammatory damage occurs in the special immunosuppressive microenvironment of the testis, a hallmark termed testicular immune privilege, which allows tolerance to neo-antigens from developing germ cells appearing at puberty, long after the establishment of systemic immune tolerance. Experimental autoimmune orchitis (EAO) is a well-established rodent model of chronic testicular inflammation and organ specific autoimmunity that offers a valuable in vivo tool to investigate the pathological and molecular mechanisms leading to the breakdown of the testicular immune privilege. The disease is characterized by the infiltration of the interstitium by immune cells (mainly macrophages, dendritic cells, and T cells), formation of autoantibodies against testicular antigens, production of pro-inflammatory mediators such as NO, MCP1, TNF $\alpha$, IL6, or activins and dysregulation of steroidogenesis with reduced levels of serum testosterone. EAO leads to sloughing of germ cells, atrophic seminiferous tubules and fibrotic remodeling, parameters all found similarly to changes in human biopsies from infertile patients with inflammatory infiltrates. Interestingly, testosterone supplementation during the course of EAO leads to expansion of the regulatory $T$ cell population and inhibition of disease development. Knowledge of EAO pathogenesis aims to contribute to a better understanding of human testicular autoimmune disease as an essential prerequisite for improved diagnosis and treatment.

Keywords: testicular inflammation, autoimmunity, experimental autoimmune orchitis (EAO), infertility, testis immunoregulation

\section{INTRODUCTION}

Infection and inflammation of the male reproductive tract are relevant causes of infertility with a prevalence of $6-10 \%(1,2)$. Bacterial infections eliciting epididymo-orchitis are either sexually transmitted or originate from urinary infections often resulting from ascending canalicular infections of the male excurrent ducts. Also, a number of systemically transmitted viruses (mumps virus, HIV and ZIKV virus, among others) are able to induce orchitis. Inflammation of the male reproductive tract is associated not only with infections but also with aging and diseases that damage germ cells (GC) including testis cancer, obesity, cryptorchidism and systemic autoimmune diseases, as well as trauma and toxic agents (3-7). 
Autoimmune infertility has long been postulated as one of the causes of infertility, even though a well-defined entity has not yet been established. However, it is relevant that focal lymphocytic infiltrations have been detected in $25-30 \%$ of testicular biopsies from infertile patients $(8,9)$. Anti-sperm antibodies (ASA) have been mainly detected in patients with obstructive azoospermia (10). However, there is so far no close association between ASA and male genital tract inflammation $(11,12)$ except for some reports associating ASA with idiopathic granulomatous orchitis $(13,14)$ and a history of epididymitis/orchitis (15). Our own studies reported significantly elevated titers of autoantibodies against disulphide isomerase family A, member 3 (ER-60) in sera from infertile azoospermic patients with histologically confirmed low-grade testicular inflammation (16). Further, the major evidence for an autoimmune basis of human orchitis comes from patients with autoimmune polyendocrine syndrome APS-type 1 caused by AIRE gene mutation which induces testis impairment and antibodies to Leydig cell antigens (17).

Experimental autoimmune orchitis (EAO) is a well-established rodent model of organ specific autoimmunity that provides a very valuable in vivo tool to investigate pathological, immune and molecular mechanisms involved in chronic testicular inflammation.

\section{EXPERIMENTAL MODELS OF AUTOIMMUNE ORCHITIS}

Research on spontaneous autoimmune orchitis in mink (18, $19)$ and rodents after vasectomy (20), thymectomy $(21,22)$, or genetic manipulation (23) have constructed a body of evidence for better understanding of systemic and peripheral tolerance. Studies in classical rodent EAO models induced by antigen immunization have also clarified pathological mechanisms of autoimmune-based testicular inflammation [reviewed in $(8,24)]$.

The first report on a classical EAO model was published by Voisin et al. (25) who injected testicular tissue and adjuvants into guinea pigs. However, it was Freund et al. (26) who clarified the organ and species specificity of the model. In a murine model, EAO susceptibility depends of genetic background of each strain (27). Further progress on the pathogenesis of EAO has come from mouse and rat models, initiated by Tung and colleagues (28) and Doncel et al. (29), respectively. A description of the histopathology, mechanisms of disease initiation and testicular inflammation are discussed below.

Current rat and mouse EAO models utilizing testicular homogenate in complete Freund's adjuvant plus pertussis toxin (8), vasectomized mouse model (20), and mouse EAO model without adjuvants (30) have provided novel insights into orchitogenic antigens. Most of these antigens, identified by sera obtained from animals with EAO, are not testis-specific except zonadhesin or outer dense fiber major protein 2 (30-32).

\section{IMMUNE PRIVILEGE OF THE TESTIS}

Testicular homeostasis that protects GC from immune attack is known to be maintained by structural components such as the blood-testis barrier (BTB) and systemic and local tolerance mechanisms. In contrast with the previous testis antigen sequestration paradigm, some meiotic germ cell antigens, located in the adluminal compartment of the seminiferous tubules (ST) behind the BTB, are continuously released into the interstitial space despite an intact BTB. Systemic tolerance involving antigen-specific regulatory $\mathrm{T}$ cells (Tregs) is maintained in peripheral lymphoid organs by continuously egressing germ cell antigens via transcytosis in Sertoli cells (33). Originally, the testis was defined as an immune-privileged site since it was demonstrated that foreign-tissue grafts placed within the testis are tolerated and survive for several days longer than when these grafts are implanted in conventional body sites (34). Currently, testicular immune privilege is understood as the coordinated regulation of immunologic components to protect GC, including active processes associated with Sertoli cells, peritubular cells, Leydig cells, tolerogenic antigen-presenting cells, $\mathrm{T}$ cells and the production of immune-regulatory factors such as TGF $\beta$, IL10, and activin [reviewed in (35-37)]. Several reviews suggest galectin-1 (Lgals1) as a putative candidate involved in the maintenance of testis immune privilege, mainly based on its expression by Sertoli cells (38-40). However, a significant reduction in the incidence and severity of EAO was observed in Lgals $1^{-/-}$deficient vs. wild-type mice (41) adding a note of caution to this discussion. Indoleamine-2,3dioxygenase (IDO) expression in porcine Sertoli cells and the ability of these cells to restore immune tolerance in NOD mice (42) point to a role of IDO in testis immune privilege. Current findings from functional in vivo experimental studies confirm that tryptophan metabolism modulates inflammatory immune response to spermatic antigens (43).

The BTB is formed by cell junctions of adjacent Sertoli cells at the base of the ST. It is constituted by multiple cell junction types including tight junctions, basal ectoplasmic specializations, gap junctions and desmosome-like junctions. Various integral tight junction proteins have been described between adjacent Sertoli cells with occludin and claudin 11 being the most important for barrier integrity (44). These proteins link to the actin cytoskeleton via cytoplasmic plaque proteins including zonula occludens-1,-2, and -3 , and provide links to other junctional types (gap-, adherens-) in the BTB (45). Ectoplasmic specialization-mediated adhesion is largely constituted by the cadherin-catenin multifunctional complex (46). Gap junctions are cell-cell channels that allow diffusion of metabolites, second messengers, ions, and other molecules smaller than $1 \mathrm{kDa}$, being Cx43 the dominant gap junction protein within the ST (47). Testosterone, nitric oxide (NO), cytokines and growth factors regulate the stability or localization of proteins at the BTB (48$50)$. The BTB is a dynamic ultrastructure that transiently "opens" and "closes" during the movement of preleptotene/leptotene spermatocytes to the adluminal compartment without causing failure of BTB function. As leptotene spermatocytes transit toward the tubule lumen, junction disassembly ahead of spermatocytes is coordinated by junction assembly behind these GC so that the two spermatogenic events are synchronized (46). Moreover, the presence of specific transporters located along the basolateral membrane of Sertoli cells that allow the passage of 
selective molecules while restricting the entry of others, makes the BTB a physiological barrier crucial for the development and maturation of GC.

\section{HISTOPATHOLOGY AND MECHANISMS OF TESTICULAR INFLAMMATION IN RODENT EAO MODEL}

Testis histopathology in EAO is characterized by an increase in the number of dendritic cells (DC), macrophages $(\mathrm{M} \phi)$, mast cells and $\mathrm{T}$ lymphocytes (L) distributed in the interstitium close to ST, exhibiting different degrees of GC sloughing (mainly spermatids and spermatocytes). Germ cell apoptosis and multinucleated spermatids in the lumen of ST as well as vacuolization in the cytoplasm of Sertoli cell are frequently observed. Damage of ST is initially focal, followed by development of severe orchitis showing aspermatogenesis and fibrosis of the wall of most ST (Figure 1). L and M $\phi$ distributed in the interstitium might enter the ST in mice as well as in humans in contrast to rats. Large granulomae are frequently observed. Hyperplasia and hypertrophy of Leydig cells and an increased number of small blood vessels are also detected (Figure 2).

\section{Blood Testis Barrier}

During testicular inflammation BTB integrity is impaireddenoted by increased permeability to tracers $(52,53)$. Concomitantly, changes in expression of cell junction adhesion molecules were detected. A decrease in occludin and Cx43 expression and an increase in the expression of $\mathrm{N}$-cadherin and $\alpha$-catenin were observed in testis of rats with $\operatorname{EAO}(53,54)$.

Increased levels of inflammatory cytokines in the EAO testis alter the normal function of the BTB. Local administration of IL17A into the rat testis increases BTB permeability by reducing occludin expression and delocalization of claudin-11 (55). IL6 impairs the Sertoli cell tight junction barrier in normal rats by perturbing the MAPK14 signaling pathway and inhibiting BTBconstituent protein degradation $(54,56)$. TNF $\alpha$ administered locally to adult rat testis inhibits the steady-state protein levels of occludin, ZO-1, and N-cadherin altering the BTB function (57).

\section{Dendritic Cells}

The maturation state of DC cells is regarded as a control point for the induction of peripheral tolerance or autoimmunity. Purified DC from EAO rat testes demonstrated significantly upregulated expression of the chemokine receptor CCR7, which is responsible for the migration of DC to the draining lymph nodes (58). Moreover, the expression of IL10 and IL12p35 transcripts were detectable only in DC from inflamed testes, pointing to a mature immunogenic state before imminent migration to the lymph nodes. DC in draining lymph nodes from rats with $\mathrm{EAO}$ are mature, present antigens to $\mathrm{T}$ cells, and stimulate an autoimmune response against testicular antigens, thereby causing immunological disturbances of the testis (59).

\section{Macrophages}

A large population of resident $\mathrm{M} \phi$ subsets in the interstitium of normal testis is in close association with Leydig cells (60). Testicular M $\phi$ modulate spermatogenesis, steroidogenesis and also BTB permeability in the normal testis (61). Once testicular immune privilege is disrupted by immunization with spermatic antigens, the number of $\mathrm{M} \phi$ progressively increases in the testicular interstitium. Chemokines, mainly MCP1, acting on endothelial cells, facilitate infiltration into the testis of $\mathrm{CD}^{+} 8^{+}$ $\mathrm{CD}_{163}{ }^{-}$monocytes from circulation, expressing the MCP1 receptor CCR2 $(62,63)$. Most of these infiltrating $\mathrm{M} \phi$ express MHCII molecules and secrete pro-inflammatory mediators, mainly $\mathrm{TNF} \alpha$, IL6, and NO involved in BTB impairment, lymphocyte infiltration, and germ cell apoptosis (53, 64-66). Depletion of $\mathrm{M} \phi$ by in vivo administration of liposomes containing clodronate significantly reduced the incidence and severity of EAO, thereby highlighting the requirement of these cells for disease induction (63).

\section{T Cells}

From the early focal EAO stage onwards, a large increase in the number of $\mathrm{CD}^{+}$and $\mathrm{CD}^{+} \mathrm{T}$ cells occurs in the interstitium in association with increasing damage of ST (67). Interestingly, in a mouse EAO testis, a population of double positive $\mathrm{CD} 4^{+} \mathrm{CD} 8^{+}$ $\mathrm{T}$ cells was detected (68). However, the function of these cells in the periphery is not very well-investigated. TNF $\alpha$ and IFN $\curlyvee-$ producing Th1 cells and IL17-producing Th17 cells govern the early stage of EAO while $\mathrm{CD}^{+} \mathrm{T}$ cells $\left(\mathrm{TNF} \alpha^{+}, \mathrm{IFN} \gamma^{+}\right.$, and $\mathrm{IL}_{1}{ }^{+}$) lead the disease to its chronic severe stage (69). Besides being the main source of Th1 and Th17 cytokines in the chronically inflamed testis, $\mathrm{CD}^{+}$cells are the main subset expressing the CD25 activation marker (67). Together with the influx of auto-pathogenic T cells, $\mathrm{CD}^{+}$and $\mathrm{CD}^{+}$cells with regulatory phenotype (Tregs) also accumulate in EAO testis and in the lymph nodes draining the testis (TLN) $(67,70)$. These subsets show dynamic behavior during EAO progression; interstitial $\mathrm{CD}^{+}{ }^{+}$Foxp $^{+}$Tregs reach a maximum number at the early stage of EAO and then decline at the chronic stage. However, the number of $\mathrm{CD} 8^{+}$Foxp $3^{+}$subset that increases to a lesser extent than their $\mathrm{CD}^{+}{ }^{+}$Foxp $^{+}$counterparts during EAO onset remains stable throughout disease. The regulatory function of this subset was not evaluated. Most CD4+ Foxp3+ Tregs from TLN display an antigen-experienced phenotype and also express TGF- $\beta$. In vitro suppression studies showed that $\mathrm{CD} 4^{+}$Foxp $3^{+}$ Tregs derived from EAO TLN suppress T cell proliferation more efficiently than their counterparts derived from normal TLN, suggesting that EAO Tregs are over-activated by inflammation (70). However, Tregs present in the testicular inflammatory microenvironment fail to counteract deleterious autoimmune effects on GC; consequently, tissue damage progresses (71).

\section{Germ Cells}

In EAO testis, GC death occurs through apoptotic mechanisms involving FasL-Fas, TNF $\alpha-T N F R$, IL6-IL6R, and NO-NOS systems, via autocrine or paracrine pathways. The number of apoptotic GC sloughed from the seminiferous epithelium expressing Fas, TNFR, or IL6R increases with progression of 


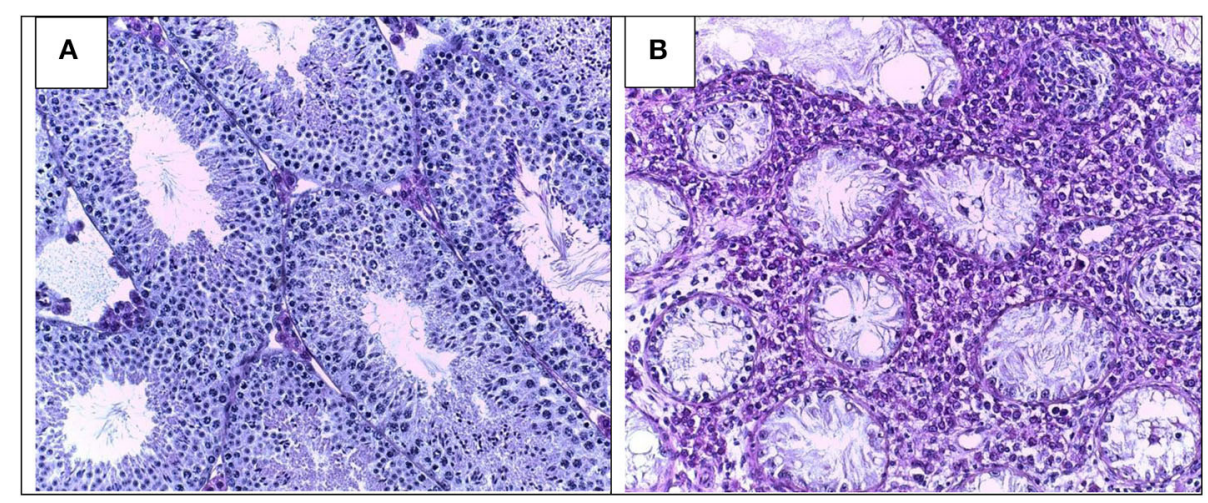

FIGURE 1 | Testicular histology in normal (A) and severe EAO (B) mouse testis. Typical histopathological changes include infiltration of the interstitium by immune cells, sloughing of germ cells leading to aspermatogenesis, vacuolization of Sertoli cells cytoplasm, thickening of lamina propria, extensive necrosis, and fibrosis of seminiferous tubules (magnification $\times 200$ ).
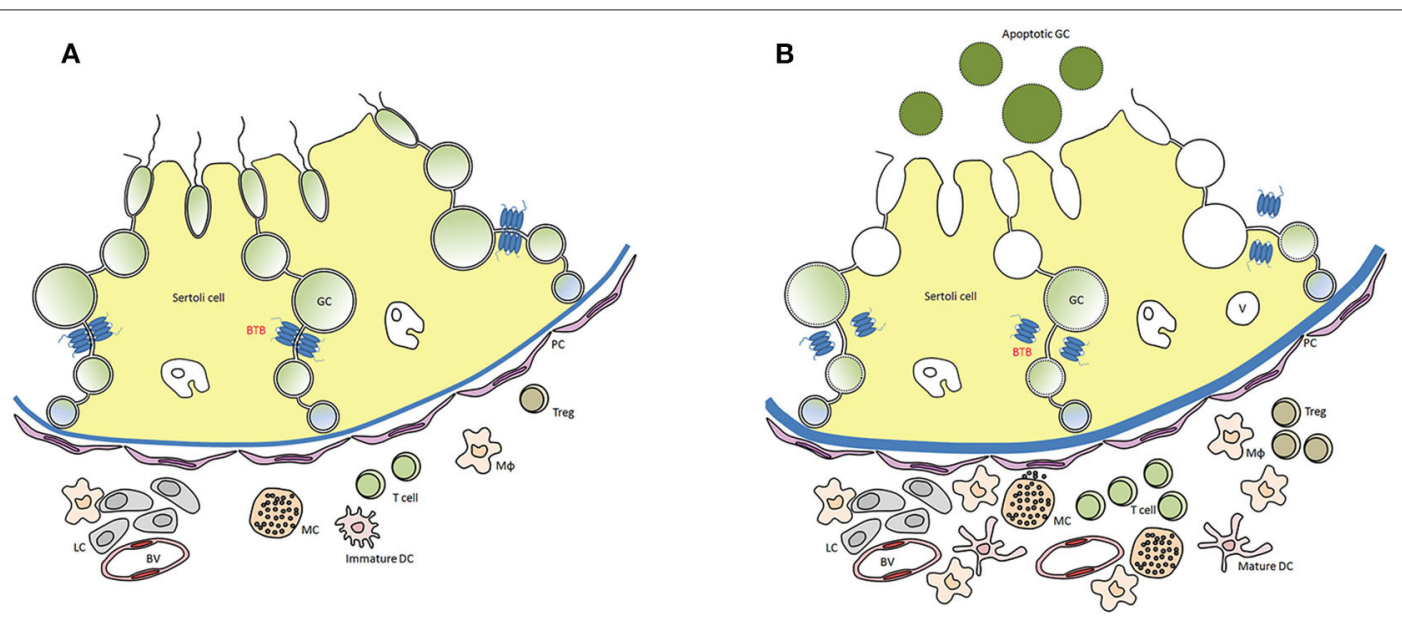

FIGURE 2 | Distribution of immune cells in a rodent testis section under normal (A) and inflammatory conditions (EAO) (B). In EAO, dendritic cells (DC), macrophages $(\mathrm{M} \Phi)$, T cells, regulatory T cells (Treg), and mast cells (MC) are increased in number and distributed in the interstitium, mainly in the peritubular area of damaged seminiferous tubules (ST). Some MC are located in a close proximity to peritubular cells (PC). Impairment of blood testis barrier (BTB) and disturbances of spermatogenesis (presence of apoptotic germ cells in the ST lumen) are illustrated; BV, blood vessel; v, vacuole in Sertoli cell cytoplasm [modified from (51)].

testicular damage $(66,72,73)$. With the influx of $\mathrm{T}$ cells expressing FasL, the content of the soluble form of FasL increases in the interstitial fluid. This factor is capable of crossing the altered BTB in inflammation, and triggers Fas-sensitive germ cell apoptosis (74). TNF $\alpha$ produced in large quantities by resident $\mathrm{M} \phi$, infiltrating monocytes, and also by $\mathrm{T}$ cells induces apoptosis of spermatocytes and spermatids expressing TNFR1 (66, 72, 74). IL6 secreted by infiltrating M $\phi$, Leydig, and peritubular cells activates executioner caspase-3, resulting in apoptosis of IL6R ${ }^{+}$ GC (73).

An oxidative microenvironment is generated in EAO testis by high levels of NO, produced mainly by both resident and infiltrating $\mathrm{M} \phi$ (65). NO reaches ST and induces basal germ cell apoptosis by activating the mitochondrial pathway. Spermatogonia are likely sensitive to oxidative stress generated by $\mathrm{NO}$ since DETA-NO, a compound that releases NO, induces cell cycle arrest and apoptosis in GC-1 cell line (75).
Apoptosis in EAO testis occurs via a cytokine-dependent amplification loop resulting from the activation of death receptors and oxidative damage of GC. This phenomenon is sustained by the ongoing influx of immune cells into the testicular interstitium.

\section{FIBROTIC RESPONSE-INVOLVEMENT OF ACTIVIN A}

In severe EAO fibrotic remodeling is a hallmark of the disease. Fibrotic changes are initiated around the ST and show excessive production and deposition of extracellular matrix proteins such as fibronectin and collagens and a thickening of the lamina propria. The fibrotic alterations are accompanied by changes in the morphological appearance and thickening of the $\alpha$-smooth muscle actin layer in the peritubular cells, belonging to the 
population of myofibroblasts in the testis $(68,76)$. Expression of fibronectin correlates positively with the disease damage score and fibrosis. Moreover, there is strong correlation between activin A concentrations and fibrotic damage in EAO testis (76). These changes show-also in human biopsies from patients with Sertoli cell only syndrom-a clear relationship between activin A expression-and lymphocytic infiltrates (76). Stimulation of peritubular cells by activin A increased levels of fibronectin and collagen I and IV implicating activin A as an important mediator of fibrotic remodeling during testicular inflammation (76). This underlines a function for activin A beside its classical endocrine function in inducing follicle stimulating hormone (FSH) secretion from the pituitary but increasingly as an important regulator of inflammation and fibrosis in many organs (77). Activin A is broadly expressed in testicular cells and stimulation of cultured Sertoli cells with TNF $\alpha$ leads to elevated expression of activin A (76). However, elevating circulating levels of follistatin, an endogenous antagonist of the activins prior to EAO induction was not sufficient to fully inhibit the disease development, although the severity of the disease and the extent of the fibrotic damage was reduced (52).

\section{HORMONAL REGULATION DURING INFLAMMATORY PHASE OF THE DISEASE}

The hormonal status of EAO animals shows disturbances of the hypothalamic-testicular axis at several levels. In EAO rats the levels of FSH are increased while the concentration of testosterone in serum is significantly downregulated (78-80). In contrast, the levels of intratesticular testosterone were either upregulated or unchanged, depending on the scientific report (78-80). Earlier in vitro experiments demonstrated that basal and human chorionic gonadotropin (hCG) stimulated testosterone production were significantly elevated in EAO testis (81). Moreover, Leydig cells from EAO testis in vitro showed an increased basal and hCG stimulated testosterone production compared to cells from control animals. Stimulation with TNF $\alpha$ inhibited this effect (72). Interestingly, testosterone substitution of EAO rats demonstrated a reduction of macrophage accumulation and CD4 $+\mathrm{T}$ cell influx at the testicular level, while the numbers of regulatory CD4+CD25+Foxp3+ T cells were increased. Testosterone treatment induced a strong increase in the number of regulatory $\mathrm{T}$ cells in vivo and in vitro $(80,82)$. Of note, androgens through androgen receptor modulate expression of Foxp3 (83) (Table 1).

\section{INVOLVEMENT OF THE EPIDIDYMIS}

In EAO mice, the epididymis underwent a region-specific immune response positively correlating to the severity of orchitis $(28,84)$. Similar to the observed differential immune responsiveness in a model of acute bacterial epididymitis $(85,86)$, the distally located cauda epididymidis and vas deferens show a severe immune reaction in EAO mice characterized by an upregulated expression of cytokines and immunomodulatory factors (Tgfb1, Ccl2, Il1b, Il10, Tnf, Foxp3, Ido1), immune
TABLE 1 | Pathological events leading to development of experimental autoimmune orchitis (EAO).
Structural and functional changes in Sertoli cells

Immunopathology

Disturbances of spermatogenesis

Hormonal changes Chronic phase of disease
Impairment of BTB structure and function by the action of pro-inflammatory cytokines mainly secreted by immune cells

Vacuolization of Sertoli cell cytoplasm

Testicular dendritic cells (DC) become mature migrate to the testis-draining lymph nodes (TLN) and activate $T$ cells

Inflammatory macrophages $(\mathrm{M} \Phi)$, DC, effector $\mathrm{T}$ lymphocytes (Th1, Th17, and $\mathrm{CD}^{+}$) and mast cells (MC), infiltrate the testis

$\mathrm{CD}^{+}{ }^{+} \mathrm{Foxp}^{+}{ }^{+}$regulatory $\mathrm{T}$ lymphocytes (Tregs) actively accumulate within the testis and TLN Small vessels increase in number and chemokines enhance immune cell infiltration

Tregs present in the testis fail to counterbalance immunoreactions that cause deleterious effects on germ cells (GC)

Antigens released from damaged seminiferous tubules (ST) amplify the autoimmune response leading to continuous antigen presentation to $T$ lymphocytes in TLN (chronification of orchitis)

GC apoptosis and sloughing in the tubular lumen mainly induced by the action of TNF $\alpha$, IL6, NO, and Fas ligand

Impairment of androgen production

Aspermatogenesis, ST atrophy, fibrosis and thickening of ST wall

Infertility cell infiltration, fibrosis and epithelial damage resulting in a loss of tissue integrity and subsequent aggregation of displaced spermatozoa within the interstitium (84). The proximal regions (initial segment and caput), in contrast, do not reveal histopathological alterations or an upregulated expression of cytokines, although these regions are more densely vascularized and harbor a high number of resident immune cells $(87,88)$. It needs to be noted though that data on epididymal reactions in EAO models are very scarce and thus the underlying molecular pathomechanisms remain unknown.

\section{DISCUSSION}

In summary, rodent models of EAO offer a valuable tool to discover the decisive mechanisms for the development of autoimmune-based epididymo-testicular inflammation. However, caution is necessary in extrapolating the data from rodent models to human due to several differences at the immunological and cellular level. Silent asymptomatic testicular inflammation in human is rather difficult to diagnose and treatment hampered due to missing non-invasive diagnostic tools. Possible therapeutical interventions and the development of new non-invasive diagnostic tools, such as serum assays may offer potential developments in the field gathered from the animal model. Several previous studies were already successfully dealing with the therapeutic inhibition of EAO by using e.g., depletion of $\mathrm{M} \phi$ (63), blockade of pro-inflammatory 
mediators $(41,52,64,89)$ or administration of testosterone $(80)$. Supplementation of reduced testosterone levels in EAO rats led to inhibition of disease development and suggests testosterone as an immunoregulatory and immunosuppressive factor during testicular inflammation (80). Further studies are necessary to define the biomarkers and possible targets of autoimmune-based testicular inflammation.

\section{MAIN OUTSTANDING QUESTIONS IN THE FIELD}

To further our understanding of the immunopathology of autoimmune based impairment of fertility, the following aspects would warrant attention in future research: (a) the identification of molecular mechanism that trigger the autoimmune attack in the human testis without obvious presence of pathogens, (b) the evaluation of specific genetic predisposition in humans responsible for susceptibility to autoimmune diseases of the gonads, (c) elucidation of the common features of testis

\section{REFERENCES}

1. Rowe PJ, Comhaire F, Hargreave T, Mahmoud A. WHO Manual for the Standarized Investigation, Diagnosis and Management of the Infertile Male. Cambridge: Cambridge University Press (2000).

2. Weidner W, Pilatz A, Diemer T, Schuppe HC, Rusz A, Wagenlehner F. Male urogenital infections: impact of infection and inflammation on ejaculate parameters. World J Urol. (2013) 31:717-23. doi: 10.1007/s00345-013-1082-7

3. Frungieri MB, Calandra RS, Bartke A, Matzkin ME. Ageing and inflammation in the male reproductive tract. Andrologia. (2018) 50:1-9. doi: 10.1111/and.13034

4. Klein B, Haggeney $\mathrm{T}$, Fietz D, Indumathy $\mathrm{S}$, Loveland $\mathrm{KL}$, Hedger $M$, et al. Specific immune cell and cytokine characteristics of human testicular germ cell neoplasia. Hum Reprod. (2016) 31:2192-202. doi: 10.1093/humrep/dew211

5. Leisegang $\mathrm{K}$, Henkel $\mathrm{R}$, Agarwal A. Obesity and metabolic syndrome associated with systemic inflammation and the impact on the male reproductive system. Am J Reprod Immunol. (2019) 82:e13178. doi: 10.1111/aji.13178

6. Jahnukainen K, Jorgensen N, Pollanen P, Giwercman A, Skakkebaek NE. Incidence of testicular mononuclear cell infiltrates in normal human males and in patients with germ cell neoplasia. Int J Androl. (1995) 18:31320. doi: 10.1111/j.1365-2605.1995.tb00423.x

7. Nistal M, Riestra ML, Paniagua R. Focal orchitis in undescended testes: discussion of pathogenetic mechanisms of tubular atrophy. Arch Pathol Lab Med. (2002) 126:64-9. doi: 10.1043/0003-9985(2002)126<0064:FOIUT>2.0. $\mathrm{CO} ; 2$

8. Fijak M, Pilatz A, Hedger MP, Nicolas N, Bhushan S, Michel V, et al. Infectious, inflammatory and "autoimmune" male factor infertility: how do rodent models inform clinical practice? Hum Reprod Update. (2018) 24:41641. doi: 10.1093/humupd/dmy009

9. Schuppe H-C, Pilatz A, Hossain H, Diemer T, Wagenlehner F, Weidner W. urogenital infection as a risk factor for male infertility. Dtsch Arztebl Int. (2017) 114:339-46. doi: 10.3238/arztebl.2017.0339

10. Vickram A, Dhama K, Chakraborty S, Samad HA, Latheef SK, Sharun K, et al. Role of antisperm antibodies in infertility, pregnancy, and potential forcontraceptive and antifertility vaccine designs: research progress and pioneering vision. Vaccines. (2019) 7:116. doi: 10.3390/vaccines7030116

11. Marconi M, Pilatz A, Wagenlehner F, Diemer T, Weidner W. Are antisperm antibodies really associated with proven chronic inflammatory and infectious diseases of the male reproductive tract? Eur Urol. (2009) 56:708-15. doi: 10.1016/j.eururo.2008.08.001 autoimmunity with autoimmune diseases of other organs, mainly in relation to Tregs behavior, and (d) the role of specific testicular somatic cells beside immune cells in the development of the disease.

\section{AUTHOR CONTRIBUTIONS}

LL, VG, MT, CP, PJ, CP, AM, and MF performed literature research and wrote the manuscript together. All authors reviewed and approved the final version of the manuscript.

\section{FUNDING}

International Research Training Group between Justus Liebig University of Giessen and Monash University, Melbourne (GRK 1871/1-2) on Molecular pathogenesis on male reproductive disorders funded by the Deutsche Forschungsgemeinschaft and Monash University. Universidad de Buenos Aires and Consejo Nacional de Investigaciones Científicas y Técnicas (CONICET).

12. Francavilla F, Barbonetti A. Male autoimmune infertility. In: Krause W, Naz $\mathrm{R}$, editors. Immune Infertility Impact of Immune Reactions on Human Fertility. 2nd ed. Cham: Springer International Publishing (2017) p. 187-96.

13. Aitchison M, Mufti GR, Farrell J, Paterson PJ, Scott R. Granulomatous orchitis. review of 15 cases. $\mathrm{Br}$ J Urol. (1990) 66:312-4. doi: 10.1111/j.1464-410X.1990.tb14934.x

14. Roy S, Hooda S, Parwani A V. Idiopathic granulomatous orchitis. Pathol Res Pract. (2011) 207:275-8. doi: 10.1016/j.prp.2011.02.005

15. Tchiokadze S, Galdava G. Clinical and anamnestic characteristics of development of antisperm immunity in infertile men. Georgian Med News. (2015) 246:18-22.

16. Fijak M, Zeller $T$, Huys $T$, Klug J, Wahle E, Linder $M$, et al. Autoantibodies against protein disulfide isomerase ER-60 are a diagnostic marker for low-grade testicular inflammation. Hum Reprod. (2014) 29:238292. doi: 10.1093/humrep/deu226

17. Kisand K, Peterson P. Autoimmune polyendocrinopathy candidiasis ectodermal dystrophy: known and novel aspects of the syndrome. Ann N Y Acad Sci. (2011) 1246:77-91. doi: 10.1111/j.1749-6632.2011. 06308.x

18. Pelletier RM. Cyclic formation and decay of the blood-testis barrier in the mink (Mustela vison), a seasonal breeder. Am J Anat. (1986) 175:91117. doi: 10.1002/aja.1001750109

19. Pelletier R-M, Yoon SR, Akpovi CD, Silvas E, Vitale ML. Defects in the regulatory clearance mechanisms favor the breakdown of selftolerance during spontaneous autoimmune orchitis. Am J Physiol Regul Integr Comp Physiol. (2009) 296:R743-62. doi: 10.1152/ajpregu.907 51.2008

20. Wheeler K, Tardif S, Rival C, Luu B, Bui E, Del Rio R, et al. Regulatory T cells control tolerogenic versus autoimmune response to sperm in vasectomy. Proc Natl Acad Sci USA. (2011) 108:7511-6. doi: 10.1073/pnas.1017615108

21. Taguchi O, Nishizuka Y. Experimental autoimmune orchitis after neonatal thymectomy in the mouse. Clin Exp Immunol. (1981) 46:425-34.

22. Tung KS, Smith S, Matzner P, Kasai K, Oliver J, Feuchter F, et al. Murine autoimmune oophoritis, epididymoorchitis, and gastritis induced by day 3 thymectomy. Am J Pathol. (1987) 126:303-14.

23. Taurog JD, Rival C, van Duivenvoorde LM, Satumtira N, Dorris ML, Sun M, et al. Autoimmune epididymoorchitis is essential to the pathogenesis of malespecific spondylarthritis in HLA-B27-transgenic rats. Arthritis Rheum. (2012) 64:2518-28. doi: 10.1002/art.34480

24. Lustig L, Guazzone VA, Tung KSK. Autoimmune orchitis and autoimmune oophoritis. In: Rose N, Mackay I, editors. The Autoimmune Diseases. 6th ed. London: Elsevier Inc. (2019) p. 1235-51. 
25. Voisin GA, Delauney A, Barber M. Sur les lesions testiculaires provoquee's chez les cobayes par iso- et autosensibilisation. Ann Inst Pasteur. (1951) 81:48-63.

26. Freund J, Lipton MM, Thompson GE. Aspermatogenesis in the guinea pig induced by testicular tissue and adjuvants. J Exp Med. (1953) 97:71126. doi: 10.1084/jem.97.5.711

27. Teuscher C, Smith SM, Goldberg EH, Shearer GM, Tung KS. Experimental allergic orchitis in mice. I. genetic control of susceptibility and resistance to induction of autoimmune orchitis. Immunogenetics. (1985) 22:32333. doi: 10.1007/BF00430916

28. Kohno S, Munoz JA, Williams TM, Teuscher C, Bernard CC, Tung KS. Immunopathology of murine experimental allergic orchitis. J Immunol. (1983) 130:2675-82.

29. Doncel GF, Di Paola JA, Lustig L. Sequential study of the histopathology and cellular and humoral immune response during the development of an autoimmune orchitis in Wistar rats. Am J Reprod Immunol. (1989) 20:4451. doi: 10.1111/j.1600-0897.1989.tb00638.x

30. Terayama H, Hirai S, Naito M, Qu N, Katagiri C, Nagahori K, et al. Specific autoantigens identified by sera obtained from mice that are immunized with testicular germ cells alone. Sci Rep. (2016) 6:35599. doi: 10.1038/srep 35599

31. Fijak M, Iosub R, Schneider E, Linder M, Respondek K, Klug J, et al. Identification of immunodominant autoantigens in rat autoimmune orchitis. J Pathol. (2005) 207:127-38. doi: 10.1002/path.1828

32. Tardif S, Brady HA, Breazeale KR, Bi M, Thompson LD, Bruemmer JE, et al. Zonadhesin D3-polypeptides vary among species but are similar in Equus species capable of interbreeding. Biol Reprod. (2010) 82:41321. doi: 10.1095/biolreprod.109.077891

33. Tung KSK, Harakal J, Qiao H, Rival C, Li JCH, Paul AGA, et al. Egress of sperm autoantigen from seminiferous tubules maintains systemic tolerance. $J$ Clin Invest. (2017) 127:1046-60. doi: 10.1172/JCI89927

34. Head JR, Neaves WB, Billingham RE. Immune privilege in the testis. I. basic parameters of allograft survival. Transplantation. (1983) 36:42331. doi: 10.1097/00007890-198310000-00014

35. Arck P, Solano ME, Walecki M, Meinhardt A. The immune privilege of testis and gravid uterus: same difference? Mol Cell Endocrinol. (2014) 382:50920. doi: 10.1016/j.mce.2013.09.022

36. Fijak M, Meinhardt A. The testis in immune privilege. Immunol Rev. (2006) 213:66-81. doi: 10.1111/j.1600-065X.2006.00438.x

37. Schuppe HC, Meinhardt A. Immune privilege and inflammation of the testis. Chem Immunol Allergy. (2005) 88:1-14. doi: 10.1159/0000 87816

38. Chui K, Trivedi A, Cheng CY, Cherbavaz DB, Dazin PF, Huynh ALT, et al. Characterization and functionality of proliferative human Sertoli cells. Cell Transplant. (2011) 20:619-35. doi: 10.3727/096368910X536563

39. Dettin L, Rubinstein N, Aoki A, Rabinovich GA, Maldonado CA. Regulated expression and ultrastructural localization of galectin-1, a proapoptotic betagalactoside-binding lectin, during spermatogenesis in rat testis. Biol Reprod. (2003) 68:51-9. doi: 10.1095/biolreprod.102.006361

40. Timmons PM, Rigby PWJ, Poirier F. The murine seminiferous epithelial cycle is pre-figured in the Sertoli cells of the embryonic testis. Development. (2002) 129:635-47.

41. Pérez C V, Gómez LG, Gualdoni GS, Lustig L, Rabinovich GA, Guazzone VA. Dual roles of endogenous and exogenous galectin-1 in the control of testicular immunopathology. Sci Rep. (2015) 5:12259. doi: 10.1038/srep12259

42. Fallarino F, Luca G, Calvitti M, Mancuso F, Nastruzzi C, Fioretti MC, et al. Therapy of experimental type 1 diabetes by isolated Sertoli cell xenografts alone. J Exp Med. (2009) 206:2511-26. doi: 10.1084/jem.20090134

43. Gualdoni GS, Jacobo P V, Sobarzo CM, Pérez C V, Matzkin ME, Höcht C, et al. Role of indoleamine 2,3-dioxygenase in testicular immune-privilege. Sci Rep. (2019) 9:15919. doi: 10.1038/s41598-019-52192-8

44. França LR, Hess RA, Dufour JM, Hofmann MC, Griswold MD. The Sertoli cell: one hundred fifty years of beauty and plasticity. Andrology. (2016) 4:189-212. doi: 10.1111/andr.12165

45. Stanton PG. Regulation of the blood-testis barrier. Semin Cell Dev Biol. (2016) 59:166-73. doi: 10.1016/j.semcdb.2016.06.018

46. Mruk DD, Cheng CY. The mammalian blood-testis barrier: its biology and regulation. Endocr Rev. (2015) 36:564-91. doi: 10.1210/er.2014-1101
47. Gerber J, Heinrich J, Brehm R. Blood-testis barrier and Sertoli cell function: lessons from SCCx43KO mice. Reproduction. (2016) 151:R1527. doi: 10.1530/REP-15-0366

48. Lee NPY, Mruk DD, Wong C-H, Cheng CY. Regulation of Sertoli-germ cell adherens junction dynamics in the testis via the nitric oxide synthase (NOS)/cGMP/protein kinase G (PRKG)/beta-catenin (CATNB) signaling pathway: an in vitro and in vivo study. Biol Reprod. (2005) 73:45871. doi: 10.1095/biolreprod.105.040766

49. Meng J, Holdcraft RW, Shima JE, Griswold MD, Braun RE. Androgens regulate the permeability of the blood-testis barrier. Proc Natl Acad Sci USA. (2005) 102:16696-700. doi: 10.1073/pnas.0506084102

50. Wang R-S, Yeh S, Chen L-M, Lin H-Y, Zhang C, Ni J, et al. Androgen receptor in sertoli cell is essential for germ cell nursery and junctional complex formation in mouse testes. Endocrinology. (2006) 147:562433. doi: 10.1210/en.2006-0138

51. Pérez C V, Theas MS, Jacobo P V, Jarazo-Dietrich S, Guazzone VA, Lustig L. Dual role of immune cells in the testis: protective or pathogenic for germ cells? Spermatogenesis. (2013) 3:e23870. doi: 10.4161/spmg.23870

52. Nicolas N, Muir JA, Hayward S, Chen JL, Stanton PG, Gregorevic P, et al. Induction of experimental autoimmune orchitis in mice: responses to elevated circulating levels of the activin-binding protein, follistatin. Reproduction. (2017) 154:293-305. doi: 10.1530/REP-17-0010

53. Pérez CV, Sobarzo CM, Jacobo PV, Pellizzari EH, Cigorraga SB, Denduchis B, et al. Loss of occludin expression and impairment of blood-testis barrier permeability in rats with autoimmune orchitis: effect of interleukin 6 on Sertoli cell tight junctions. Biol Reprod. (2012) 87:122. doi: 10.1095/biolreprod.112.101709

54. Pérez C, Sobarzo C, Jacobo P, Jarazo Dietrich S, Theas M, Denduchis B, et al. Impaired expression and distribution of adherens and gap junction proteins in the seminiferous tubules of rats undergoing autoimmune orchitis. Int $J$ Androl. (2011) 34(Pt. 2):e566-77. doi: 10.1111/j.1365-2605.2011.01165.x

55. Pérez CV, Pellizzari EH, Cigorraga SB, Galardo MN, Naito M, Lustig L, et al. IL17A impairs blood-testis barrier integrity and induces testicular inflammation. Cell Tissue Res. (2014) 358:885-98. doi: 10.1007/s00441-014-1995-5

56. Zhang $\mathrm{H}$, Yin $\mathrm{Y}$, Wang $\mathrm{G}$, Liu $\mathrm{Z}$, Liu $\mathrm{L}$, Sun F. Interleukin-6 disrupts blood-testis barrier through inhibiting protein degradation or activating phosphorylated ERK in Sertoli cells. Sci Rep. (2014) 4:4260. doi: 10.1038/srep04260

57. Li MWM, Xia W, Mruk DD, Wang CQF, Yan HHN, Siu MKY, et al. Tumor necrosis factor \{alpha\} reversibly disrupts the blood-testis barrier and impairs Sertoli-germ cell adhesion in the seminiferous epithelium of adult rat testes. $J$ Endocrinol. (2006) 190:313-29. doi: 10.1677/joe.1.06781

58. Rival C, Guazzone VA, von Wulffen W, Hackstein H, Schneider E, Lustig L, et al. Expression of co-stimulatory molecules, chemokine receptors and proinflammatory cytokines in dendritic cells from normal and chronically inflamed rat testis. Mol Hum Reprod. (2007) 13:85361. doi: 10.1093/molehr/gam067

59. Guazzone VA, Hollwegs S, Mardirosian M, Jacobo P, Hackstein H, Wygrecka $\mathrm{M}$, et al. Characterization of dendritic cells in testicular draining lymph nodes in a rat model of experimental autoimmune orchitis. Int J Androl. (2011) 34:276-89. doi: 10.1111/j.1365-2605.2010.01082.x

60. Hutson JC. Physiologic interactions between macrophages and Leydig cells. Exp Biol Med. (2006) 231:1-7. doi: 10.1177/153537020623100101

61. Mossadegh-Keller N, Sieweke MH. Testicular macrophages: Guardians of fertility. Cell Immunol. (2018) 330:120-5. doi: 10.1016/j.cellimm.2018.03.009

62. Guazzone VA, Rival C, Denduchis B, Lustig L. Monocyte chemoattractant protein-1 (MCP-1/CCL2) in experimental autoimmune orchitis. J Reprod Immunol. (2003) 60:143-57. doi: 10.1016/j.jri.2003.08.001

63. Rival C, Theas MS, Suescun MO, Jacobo P, Guazzone V, van Rooijen $\mathrm{N}$, et al. Functional and phenotypic characteristics of testicular macrophages in experimental autoimmune orchitis. J Pathol. (2008) 215:108-17. doi: 10.1002/path.2328

64. Jarazo Dietrich S, Fass MI, Jacobo PV, Sobarzo CMA, Lustig L, Theas MS. Inhibition of NOS-NO system prevents autoimmune orchitis development in rats: relevance of NO released by testicular macrophages in germ cell apoptosis and testosterone secretion. PLoS ONE. (2015) 10:e0128709. doi: 10.1371/journal.pone.0128709 
65. Jarazo-Dietrich S, Jacobo P, Pérez C V, Guazzone VA, Lustig L, Theas MS. Up regulation of nitric oxide synthase-nitric oxide system in the testis of rats undergoing autoimmune orchitis. Immunobiology. (2012) 217:77887. doi: 10.1016/j.imbio.2012.04.007

66. Theas MS, Rival C, Jarazo-Dietrich S, Jacobo P, Guazzone VA, Lustig L. Tumour necrosis factor-alpha released by testicular macrophages induces apoptosis of germ cells in autoimmune orchitis. Hum Reprod. (2008) 23:186572. doi: 10.1093/humrep/den240

67. Jacobo P, Guazzone VA, Jarazo-Dietrich S, Theas MS, Lustig L. Differential changes in $\mathrm{CD} 4+$ and CD8+ effector and regulatory T lymphocyte subsets in the testis of rats undergoing autoimmune orchitis. J Reprod Immunol. (2009) 81:44-54. doi: 10.1016/j.jri.2009.04.005

68. Nicolas N, Michel V, Bhushan S, Wahle E, Hayward S, Ludlow H, et al. Testicular activin and follistatin levels are elevated during the course of experimental autoimmune epididymo-orchitis in mice. Sci Rep. (2017) 7:42391. doi: 10.1038/srep42391

69. Jacobo P, Pérez CV, Theas MS, Guazzone VA, Lustig L. CD4+ and CD8+ $\mathrm{T}$ cells producing Th1 and Th17 cytokines are involved in the pathogenesis of autoimmune orchitis. Reproduction. (2011) 141:24958. doi: 10.1530/REP-10-0362

70. Jacobo P, Guazzone VA, Pérez C V, Lustig L. CD4+ Foxp3+ regulatory T cells in autoimmune orchitis: phenotypic and functional characterization. Am J Reprod Immunol. (2015) 73:109-25. doi: 10.1111/aji.12312

71. Jacobo P. The role of regulatory T Cells in autoimmune orchitis. Andrologia. (2018) 50:e13092. doi: 10.1111/and.13092

72. Suescun MO, Rival C, Theas MS, Calandra RS, Lustig L. Involvement of tumor necrosis factor-alpha in the pathogenesis of autoimmune orchitis in rats. Biol Reprod. (2003) 68:2114-21. doi: 10.1095/biolreprod.102.011189

73. Rival C, Theas MS, Guazzone VA, Lustig L. Interleukin-6 and IL-6 receptor cell expression in testis of rats with autoimmune orchitis. J Reprod Immunol. (2006) 70:43-58. doi: 10.1016/j.jri.2005.10.006

74. Jacobo PV, Fass M, Pérez CV, Jarazo-Dietrich S, Lustig L, Theas MS. Involvement of soluble Fas Ligand in germ cell apoptosis in testis of rats undergoing autoimmune orchitis. Cytokine. (2012) 60:38592. doi: 10.1016/j.cyto.2012.07.020

75. Ferreiro ME, Amarilla MS, Glienke L, Méndez CS, González C, Jacobo PV, et al. The inflammatory mediators $\mathrm{TNF} \alpha$ and nitric oxide arrest spermatogonia GC-1 cell cycle. Reprod Biol. (2019) 19:329-39. doi: 10.1016/j.repbio.2019.11.001

76. Kauerhof AC, Nicolas N, Bhushan S, Wahle E, Loveland KA, Fietz D, et al. Investigation of activin $\mathrm{A}$ in inflammatory responses of the testis and its role in the development of testicular fibrosis. Hum Reprod. (2019) 34:153650. doi: 10.1093/humrep/dez109

77. Wijayarathna R, de Kretser DM. Activins in reproductive biology and beyond. Hum Reprod Update. (2016) 22:342-57. doi: 10.1093/humupd/dmv058

78. Suescun MO, Calandra RS, Lustig L. Alterations of testicular function after induced autoimmune orchitis in rats. J Androl. (1994) 15:442-8.

79. Suescun MO, Suescun MO, Lustig L, Calandra RS, Calandra RS, Groome NP, et al. Correlation between inhibin secretion and damage of seminiferous tubules in a model of experimental autoimmune orchitis. J Endocrinol. (2001) 170:113-20. doi: 10.1677/joe.0.1700113
80. Fijak M, Schneider E, Klug J, Bhushan S, Hackstein H, Schuler G, et al. Testosterone replacement effectively inhibits the development of experimental autoimmune orchitis in rats: evidence for a direct role of testosterone on regulatory T cell expansion. J Immunol. (2011) 186:516272. doi: 10.4049/jimmunol.1001958

81. Suescun MO, Calandra RS, Lustig L. Increased testosterone production in vitro by Leydig cells from rats with severe autoimmune orchitis. Int J Androl. (1997) 20:339-46. doi: 10.1046/j.1365-2605.1998.00076.x

82. Fijak M, Damm L-J, Wenzel J-P, Aslani F, Walecki M, Wahle E, et al. Influence of testosterone on inflammatory response in testicular cells and expression of transcription factor Foxp3 in T cells. Am J Reprod Immunol. (2015) 74:12-25. doi: 10.1111/aji.12363

83. Walecki M, Eisel F, Klug J, Baal N, Paradowska-Dogan A, Wahle $\mathrm{E}$, et al. Androgen receptor modulates Foxp3 expression in CD4+CD25+Foxp3+ regulatory T-cells. Mol Biol Cell. (2015) 26:2845-57. doi: 10.1091/mbc.E14-08-1323

84. Wijayarathna R, Pasalic A, Nicolas N, Biniwale S, Ravinthiran R, Genovese $\mathrm{R}$, et al. Region-specific immune responses to autoimmune epididymitis in the murine reproductive tract. Cell Tissue Res. (2020) 381:35160. doi: 10.1007/s00441-020-03215-8

85. Michel V, Duan Y, Stoschek E, Bhushan S, Middendorff R, Young JM, et al. Uropathogenic Escherichia coli causes fibrotic remodelling of the epididymis. J Pathol. (2016) 240:15-24. doi: 10.1002/path.4748

86. Klein B, Bhushan S, Günther S, Middendorff R, Loveland KL, Hedger MP, et al. Differential tissue-specific damage caused by bacterial epididymo-orchitis in the mouse. Mol Hum Reprod. (2020) 26:215-27. doi: 10.1093/molehr/ gaaa011

87. Da Silva N, Cortez-Retamozo V, Reinecker H-C, Wildgruber M, Hill E, Brown D, et al. A dense network of dendritic cells populates the murine epididymis. Reproduction. (2011) 141:653-63. doi: 10.1530/REP10-0493

88. Battistone MA, Mendelsohn AC, Spallanzani RG, Brown D, Nair A $\mathrm{V}$, Breton S. Region-specific transcriptomic and functional signatures of mononuclear phagocytes in the epididymis. Mol Hum Reprod. (2020) 26:1429. doi: 10.1093/molehr/gaz059

89. Aslani F, Schuppe H-C, Guazzone VA, Bhushan S, Wahle E, Lochnit G, et al. Targeting high mobility group box protein 1 ameliorates testicular inflammation in experimental autoimmune orchitis. Hum Reprod. (2015) 30:417-31. doi: 10.1093/humrep/deu320

Conflict of Interest: The authors declare that the research was conducted in the absence of any commercial or financial relationships that could be construed as a potential conflict of interest.

Copyright (c) 2020 Lustig, Guazzone, Theas, Pleuger, Jacobo, Pérez, Meinhardt and Fijak. This is an open-access article distributed under the terms of the Creative Commons Attribution License (CC BY). The use, distribution or reproduction in other forums is permitted, provided the original author(s) and the copyright owner(s) are credited and that the original publication in this journal is cited, in accordance with accepted academic practice. No use, distribution or reproduction is permitted which does not comply with these terms. 